\title{
Efisiensi Kapasitas dan Biaya Produksi Kerupuk Ikan melalui Penggunaan Mesin Pengadonan pada UKM Maharani
}

\author{
Capacity Efficiency and Cost of Fish Crackers Production through the Use of Mixer Machines \\ in Maharani SMEs
}

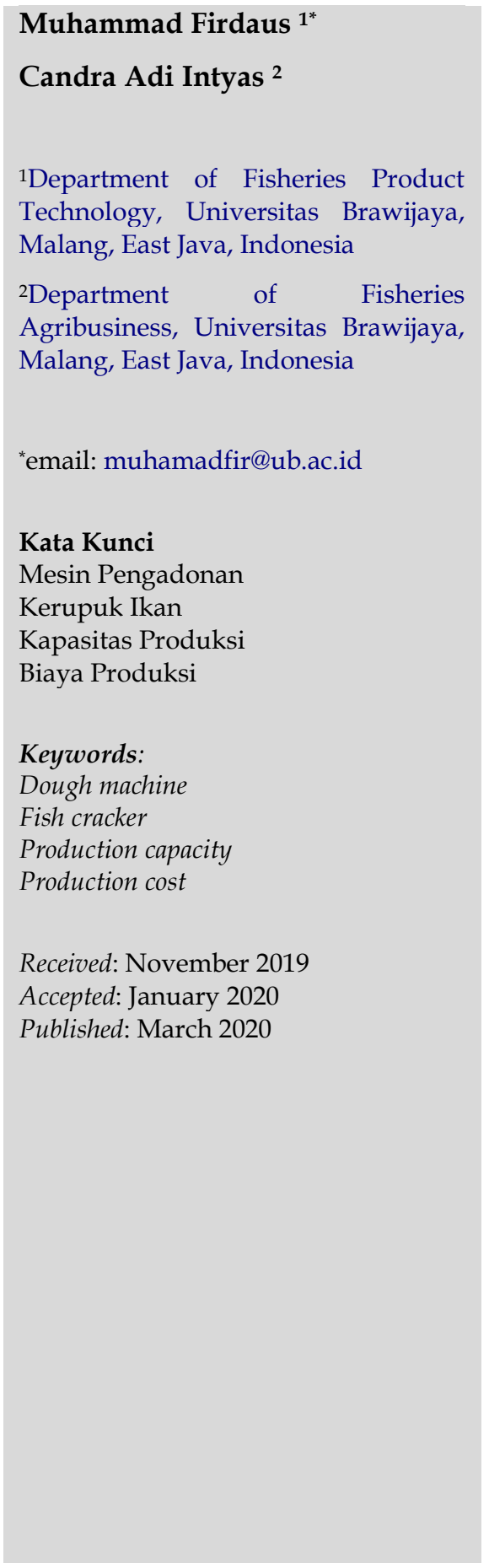

\begin{abstract}
Abstrak
Pengadonan merupakan titik kritis dalam produksi kerupuk ikan. Mitra sasaran dalam membuat adonan dengan tangan, sehingga berakibat kapasitas produksinya rendah, teksturnya tidak seragam dan harganya murah. Tujuan kegiatan ini adalah memberikan ketrampilan penggunaan mesin pengadonan kepada mitra sasaran, meningkatkan karakteristik produk, dan meningkatan kapasitas dan efisiensi biaya produksi kerupuk ikan melalui penggunaan mesin pengadonan. Mitra sasaran adalah ibu Siti Saroh, pemilik UKM. Maharani di desa Weru, kecamatan Paciran, kabupaten Lamongan. Spesifikasi mesin pengadonan yang digunakan dalam kegiatan ini memiliki sendok pengaduk sebanyak 2 buah yang bergerak berlawanan dan mesin penggeraknya berupa dinamo listrik yang bertenaga $1 / 2 \mathrm{HP}$ (370 Watt). Bahan-bahan pembuatan kerupuknya adalah tepung tapioka, campuran ikan tonang dan ikan balak, bawang putih, garam, gula, dan penyedap rasa. Metode pengabdian ini berupa pelatihan penggunaan mesin pengadonan hingga mitra, karakterisasi produk dan analisis efisiensi biaya produksi. Hasil kegiatan ini dapat meningkatkan ketrampilan mitra dalam menggunakan mesin pengadonan, kapasitas produksi meningkat 87,5 \%, produk memiliki permukaan yang lebih rata, tidak retak-retak dan bila digoreng dapat mengembang $67 \%$, dan efisiensi biaya produksinya sebesar $84,64 \%$, Kesimpulan kegiatan ini adalah penggunaan mesin pengadonan dapat meningkatkan kapasitas dan efisiensi biaya produksi kerupuk ikan.
\end{abstract}

\begin{abstract}
Making the dough is a critical point in the production of fish crackers. Target partners in making the dough by hand, so that the resulting production capacity is low, the texture is not uniform and the price is cheap. The purpose of this activity is to provide skills to use the dough machine to the target partners, improve product characteristics, and increase the capacity and cost efficiency of fish cracker production through the use of a dough machine. The target partner is Mrs. Siti Saroh, the owner of UKM. Maharani in Weru village, Paciran sub-district, Lamongan district. The specifications of the mixing machine used in this activity have as many as two moving stirring spoons and the driving machine is in the form of an electric dynamo which is powered by $1 / 2 \mathrm{HP}$ (370 Watt). The ingredients for making crackers are tapioca flour, a mixture of tonang fish and Balak fish, garlic, salt, sugar, and flavoring. This dedication method is in the form of training in the use of a dough machine to partners, product characterization and analysis of production cost efficiency. The results of this activity can improve partners' skills in using the dough machine, production capacity increases $87.5 \%$, the product has a flatter surface, does not crack and when fried can expand $67 \%$, and the efficiency of production costs by $84.64 \%$. As a conclusion, the use of mixing machines can increase the capacity and cost efficiency of fish cracker production.
\end{abstract}




\section{PENDAHULUAN}

Usaha Kecil Menengah (UKM) Kerupuk Ikan Maharani terletak di Desa Weru Kecamatan Paciran Kabupaten Lamongan Jawa Timur. Desa Weru berjarak $10 \mathrm{~km}$ dari Kecamatan dan sekitar $45 \mathrm{~km}$ menuju ke Kota Kabupaten. Tempat produksi UKM Maharani berada sekitar 10 meter dekat Tempat Pelelangan Ikan (TPI) daerah Weru. Desa Weru memiliki luas wilayah 0,11 $\mathrm{km} 2$ dan bersuhu $20-35^{\circ} \mathrm{C}$, dimana iklim ini sangat cocok untuk produksi olahan kering, termasuk kerupuk.

UKM "Maharani" adalah salah satu usaha kecil menengah mandiri yang memproduksi produk olahan ikan laut didirikan oleh ibu Siti Saroh pada tahun 2004. Ikan sebagai bahan bakunya didapat dari Tempat Pelelangan Ikan desa Weru. Salah satu produk olahan mitra adalah kerupuk ikan. Saat awal produksi ibu Siti Saroh memproduksi kerupuk ikan untuk keperluan dikonsumsi sendiri, namun semenjak tahun 2009 Ibu Siti Saroh mengembangkan produksinya untuk dijual kepada tetangga dan masyarakat Desa Weru.

Kerupuk merupakan suatu jenis makanan ringan yang sudah lama dikenal oleh sebagian besar masyarakat Indonesia. Kerupuk dapat dikonsumsi sebagai makanan selingan. Bahan tambahan yang digunakan dalam kerupuk banyak ditemukan di Indonesia seperti ikan (Taewee, 2011). Penambahan bahan tersebut sebagai bahan tambahan dalam pembuatan kerupuk dimaksudkan sebagai diversifikasi produk dengan menambah hasil perikanan untuk menambah nilai gizi dari produk kerupuk (Neiva et al., 2011). Penambahan daging ikan pada produk kerupuk dapat menambah nilai gizi pada kerupuk (Zulfahmi et al., 2014).

Cara membuat kerupuk ikan secara umum yaitu dengan bahan dasar tepung tapioka dan ikan ditambahkan dengan seluruh bahan rempah-rempah seperti bawang putih, gula, garam kemudian diuleni hingga kalis dan dikukus sekitar 2 jam. Selanjutnya didinginkan dan dipotong bulat secara tipis dan dijemur hingga kering (Zzaman et al., 2017).

Dalam sekali produksi ibu Siti Saroh dapat menghasilkan sekitar 7-8 kg kerupuk dan kapasitas produksi ini didapatkan dengan cara manual atau dengan tangan, dimana produksinya ini dimulai dari jam 3 pagi hingga 12 siang. Waktu tersebut sepenuhnya digunakan untuk mendapatkan adonan masak (benggolan). Adonan yang sudah masak selanjutnya didinginkan pada suhu ruang. Adonan yang sudah dingin pada suhu kamar ini selanjutnya dimasukkan dalam lemari pendingin dan ditempatkan pada bagian pembuatan es (freezer). Tahapan ini dilakukan selama semalam atau adonan bila ditekan sudah mengeras.

Adonan masak yang sudah mengeras ini selanjutnya diiris tipis-tipis sekitar $2 \mathrm{~mm}$ dan selanjutnya ditempatkan di atas para-para bambu. Potongan kerupuk yang sudah diatas para-para ini selanjutnya dijemur dibawah terik matahari antara pukul 7 pagi - 5 sore. Penjemuran ini membutuhkan waktu antara duatiga hari (Mokhtar \& Kresno, 2010).

Secara keseluruhan mitra sasaran dalam memproduksi 7-8 kg kerupuk kering siap dipasarkan membutuhkan waktu hingga 4 hari. Kerupuk kering produksi mitra sasaran ini dijual kepada konsumen seharga Rp 15.000,tiap kemasan 500 g. Kerupuk ikan hasil produksi ibu Siti Saroh yang dibuat secara manual memiliki penampakan tidak merata dan ada beberapa bagiannya yang retak. Gambar 1 memperlihatkan kerupuk ikan yang dibuat adonannya secara manual.

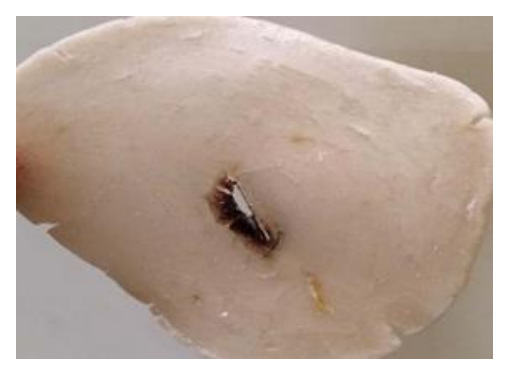

Gambar 1. Kerupuk ikan yang adonannya dibuat secara manual 
Salah satu tahapan produksi kerupuk ikan ini yang dapat diperbaiki adalah penggantian cara pengadonan. Cara pengadonan secara manual telah memakan kapasitas produksi hampir seperempat waktu produksi dan kapasitas produksinyapun terbatas serta mutu produknya rendah. Pengadonan secara mekanis dapat dilakukan dalam produksi kerupuk ikan. Penggunaan mesin pengadonan dapat mempercepat waktu kalis adonan dan jumlah adonan yang dihasilkan juga lebih banyak serta diharapkan akan menghasilkan mutu kerupuk ikan yang seragam (Rosiani et al., 2015).

Proses pengkalisan ini merupukan titik kritis dalam pembuatan kerupuk, karena adonan yang kurang kalis akan menyebabkan hasil daya kembang kerupuk kurang baik. Tanda adonan yang sudah kalis adalah dengan tidak adanya adonan yang menempel pada alat atau tangan. Adonan kalis menandakan sudah tercampurnya semua semua bahan yang ditambahkan utamanya terjadi interaksi antara pati dan protein (Slukova et al., 2017). Tujuan pengabdian ini pada UKM Maharani, desa Weru, kecamatan Paciran, kabupaten Lamongan ini adalah untuk memberikan ketrampilan penggunaan mesin pengadonan pada mitra sasaran, mendapatkan perbaikan karakteristik produk, peningkatan kapasitas produksi dan peningkatan harga kerupuk ikan melalui penggunaan mesin pengadonan.

\section{METODOLOGI}

Peralatan utama yang digunakan dalam produksi kerupuk ikan dalam kegiatan pengabdian ini adalah blender (Phillips), mesin pengadonan, timbangan, dan para-para. Mesin pengadonan yang digunakan dalam pengabdian ini terbuat dari lembaran stainless steel yang tergolong food grade yang memiliki dimensi: panjang 90 $\mathrm{cm}$, lebar $50 \mathrm{~cm}$, dan tinggi $70 \mathrm{~cm}$. Spesifikasi alat ini adalah memiliki sendok pengaduk sebanyak 2 buah yang bergerak berlawanan dan tenaga mesin penggeraknya berupa dinamo listrik $1 / 2 \mathrm{HP}$ (370 Watt) yang dilengkapi dengan reducer speed. Dimensi mesin pengadonan yang disiap terapkan oleh pelaksana pengabdian kepada mitra dapat dilihat pada Gambar 2.

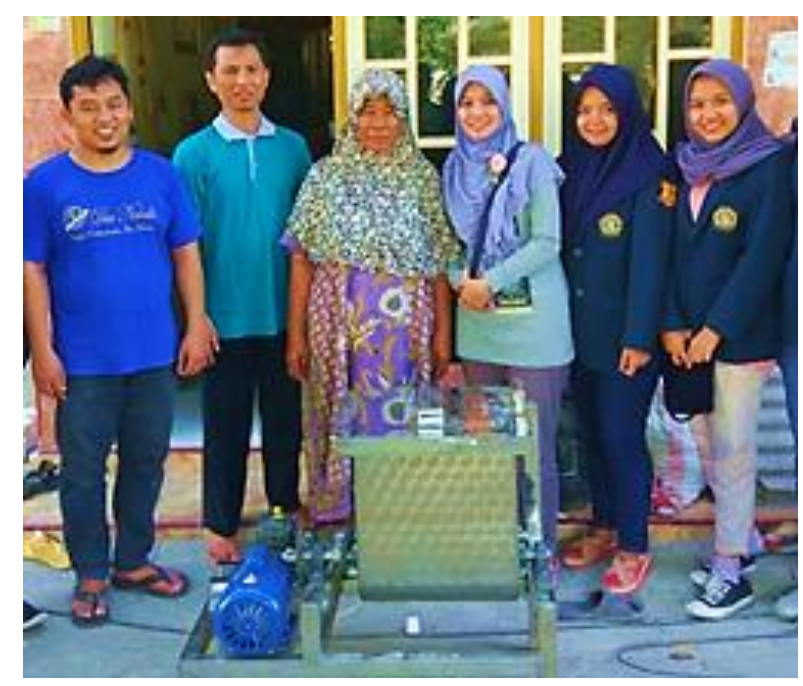

Gambar 2. Tim pelaksana bersama mahasiswa saat penyerahan mesin pengadonan kepada mitra

Bahan-bahan yang digunakan dalam pembuatan kerupuk ikan dalam kegiatan ini sebagaimana yang dilakukan oleh mitra sasaran adalah: tepung tapioka (Gunung ringgit grade A), ikan tonang (Congresox talabon) dan ikan balak (Saurida tumbil), bawang putih, garam, gula, air, dan penyedap rasa (Masako). Tahapan pengabdian ini terdiri dari tiga tahap, yaitu (1) pelatihan penggunaan mesin kepada mitra hingga terampil, (2) penggunaan mesin pengadonan dalam produksi kerupuk ikan, (3) evaluasi karakteristik dan efisiensi produk.

Tahapan pembuatan kerupuk ikan pada kegiatan ini dimulai dengan pencucian ikan, pemfiletan, pemisahan kulit dari daging dan pengecilan ukuran ikan. Ikan yang sudah berukuran kecil ini dicampur dengan air sebanyak volume ikan yang dimasukkan, lalu dilumatkan dengan blender. Bawang putih yang sudah dikupas kulitnya selanjutnya ditambah air sebanyak volume bawang putih dalam blender, selanjutnya dihaluskan dengan blender. Daging ikan lumat dan bawang putih lumat 
selanjutnya dicampur dan diaduk hingga merata, kemudian dicampurkan garam, gula, dan penyedap rasa. Selanjutnya disiapkan mesin pengadonan, dengan pelaburan bagian dasar tabung pengadonan dengan tepung tapioka. Mesin pengadonan dijalankan disesaat campuran adonan dimasukkan ke dalam mesin pengadonan. Secara perlahan tepung tapioka ditambahkan dalam campuran adonan hingga adonan menjadi kalis. Adonan yang sudah kalis ditandai dengan adonan sudah tidak melekat pada dinding atau pengaduk. Adonan kalis tersebut selanjutnya dibungkus dalam plastik untuk selanjutnya direbus dalam air hingga bagian dalamnya sudah masak, yang ditandai bagian tersebut sudah tidak lengket bila ditusuk dengan lidi daun kelapa (Zulistyanto et al., 2016). Adonan masak (benggolan) ini selanjutnya didinginkan di atas meja. Benggolan yang sudah dingin ini selanjutnya dibekukan dalam lemari es selama semalam. Benggolan yang sudah memadat ini selanjutnya diiris dengan mesin pengiris. Irisan selanjutnya ditempatkan diatas para-para dan dikeringkan dibawah terik matahari selama 2-3 hari.

Kerupuk ikan yang sudah kering selanjutnya dianalisis karakteristiknya. Karakteristik ikan yang diamati berupa permukaan, volume kembang kerupuk (Neiva et al., 2011), kapasitas produksi (Subramaniam et al., 2009), dan peningkatan harga produk (Melly \& Harni, 2016). Perlakuan dilakukan dengan membandingkan antara produk kerupuk ikan yang dihasilkan secara manual dengan yang didapat dengan mesin pengadonan.

\section{HASIL DAN PEMBAHASAN}

Hasil tahap pelatihan menunjukkan bahwa mesin pengadonan saat pertama kali digunakan masih membutuhkan penyesuaian, dimana pedal pengaduk mesin berhenti saat beban bahan-bahan adonan mulai memadat. Hal ini terjadi saat pertama kali pemakaian, semua bahan adonan sesuai komposisi langsung dimasukkan, dicampur, dan diaduk. Seiring dengan beban bahan yang harus diaduk dan bercampur langsung membentuk materi yang memadat. Hal serupa juga dilaporkan oleh Melly \& Harni (2016) bahwa bahanbahan adonan yang secara langsung dicampurkan dalam mesin pengaduk mengakibatkan mesin pengaduk berhenti. Berhentinya mesin pengaduk pada mesin pengadonan pada kegiatan pengabdian ini dapat terjadi juga karena tenaga penggeraknya yang kecil. Pada kegiatan ini, mesin pengadonan memiliki pedal pengaduk yang digerakkan oleh dinamo dengan daya 370 Watt.

Penggunaan mesin pengadonan dalam kegiatan ini oleh mitra dapat berjalan dengan baik setelah melalui penyesuaian tahapan sebanyak tiga kali, dimana pada set up yang ketiga ini, tepung tapioka harus terlebih dahulu ditaburkan dalam tabung pengaduk. kemudian baru adonan campuran ikan dan bumbu-bumbu dimasukkan secara bertahap hingga habis. Selanjutnya sambil mesin terus mengaduk campuran tepung tapioka dan bahan lainnya, terus ditambahkan tepung tapioka hingga benar-benar adonan menjadi kalis. Permukaan kerupuk ikan yang diproduksi dengan mesin pengadonan dapat dilihat pada Gambar 3.

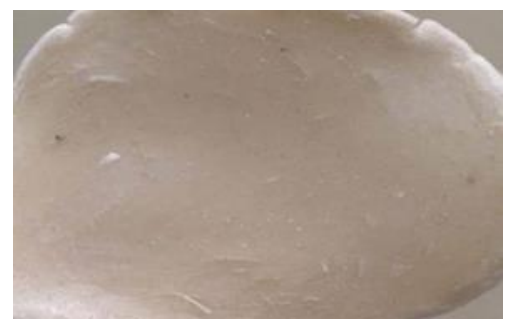

Gambar 3. Kerupuk ikan yang adonannya dibuat dengan mesin pengadonan

Gambar 3 memperlihatkan bahwa permukaan kerupuk yang diproduksi dengan mesin pengadonan lebih halus dan tidak retak-retak. Hasil ini menunjukkan bahwa proses pembentukan kalis pada adonan lebih optimal 
dengan menggunakan mesin pengadonan. Suatu adonan yang sudah kalis menggambarkan interaksi antar komponen serta dengan air dalam pengadukan sudah berlangsung sempurna dan bila digoreng akan dapat mengembang dengan maksimal (Taewee, 2011).

Proses gelatinisasi pati saat pengadonan sangat mempengaruhi volume kembang kerupuk saat digoreng. Gelatinisasi pati yang sempurna akan menghasilkan volume kembang yang maksimal. Perbedaan volume kembang kerupuk ikan sangat berhubungan dengan keberadaan amilopektin dalam adonan. Makin banyak kandungan amilopektinnya, volume kembang kerupuk tersebut makin besar. Amilopektin adalah fraksi pati yang memiliki dimensi struktur yang berongga dan struktur ini mudah menyerap air dan selanjutnya saat dipanaskan airnya terlepas dan membentuk ruang udara. Volume kembang ini selanjutnya mempengaruhi penerimaan konsumen yaitu kerenyahan. Semakin besar volume kembang produk kerupuk, maka produk tersebut makin terasa renyah (Taewee, 2011; Zulfahmi et al., 2014). Penggunaan mesin pengaduk telah mengakibatkan gelatinisasi pada adonan lebih maksimal dibanding yang dilakukan secara manual. Volume kerupuk ikan hasil dari adonan yang dibuat dengan mesin pengadon bila digoreng dapat meningkat volumenya hingga $67 \%$, sementara yang dibuat dengan manual hanya $37 \%$.

Kapasitas produksi adalah awal penentu masa depan sebuah usaha. Kesenjangan antara penawaran dan permintaan menyebabkan produksi sebuah usaha mengalami ketidakstabilan. Keputusan perencanaan kapasitas produksi bersifat strategis sebab berdampak langsung pada kemampuan suatu usaha memenuhi tingkat permintaan terhadap produknya. Kapasitas produksi itu merupakan jumlah dan jenis output maksimum yang dapat diproduksi dalam satuan waktu tertentu. Kapasitas produksi ditentukan oleh kapasitas sumberdaya yang dimiliki seperti: kapasitas mesin, tenaga kerja, bahan baku, dan modal. Kapasitas produksi dalam kegiatan pengabdian ini mengevaluasi penggunaan mesin pengadonan terhadap proses produksi pembuatan kerupuk ikan. Waktu tersisa produksi pembuatan adonan kerupuk untuk kapasitas produksi $10 \mathrm{~kg}$ dengan menggunakan mesin pengadonan 0,5 jam, sementara itu waktu produksi pembuatan adonan kerupuk ikan tanpa menggunakan mesin adalah 4 jam. Rasio ketersediaan waktu produksi dengan menggunakan mesin pengadonan adalah sebesar $87,5 \%$, artinya bahwa mesin pengadonan telah meningkatkan efisiensi produksi hampir $90 \%$ persen bila tanpa menggunakan mesin. Subramaniam et al. (2009) menjelaskan bahwa tujuan investasi industri dengan menyediakan mesin produksi adalah untuk mempersingkat waktu produksi. Makin besar rasio ketersediaan waktu yang didapat berarti mesin yang digunakan akan menghasilkan kapasitas produksi yang lebih banyak.

Penggunaan mesin dapat mengurangi kebutuhan tenaga manusia yang digunakan dalam produksi dan mengefisiensikan waktu produksinya dibandingkan pembuatan produk yang dilakukan hanya dengan tenaga manusia saja. Keadaan ini dapat mengurangi biaya tetap produksi dan meningkatkan jumlah produk yang dihasilkan. Penggunaan alat pengadonan kerupuk ini secara ekonomi lebih efisien bila dibandingkan dengan proses produksi yang dilakukan secara manual, utamanya pada biaya pokok operasi. Perbedaan nyata ini diakibatkan karena volume kapasitas kerja alat pengadon yang lebih besar dibanding secara manual danjumlah tenaga kerja yang digunakan (Melly \& Harni, 2016).

Biaya produksi merupakan suatu biaya yang berhubungan dengan fungsi produksi dalam pengolahan bahan baku menjadi produk yang sudah 
jadi. Biaya produksi juga dapat dikatakan sebagai seluruh biaya yang dikeluarkan oleh perusahaan yang berhubungan dengan fungsi atau kegiatan dalam pengolahan bahan baku menjadi produk jadi yang mempunyai nilai jual. Biaya pokok suatu produk meliputi biaya bahan baku, biaya tenaga kerja, biaya overheard pabrik. Biaya produksi dapat dihitung dengan 2 pendekatan yaitu Variable Costing (biaya tidak tetap) dan Fixed Costing (biaya tetap).

Keuntungan merupakan selisih antara biaya penerimaan dengan biaya-biaya lain selama satu tahun. Analisis keuntungan diperoleh dari besaran penerimaan dan pengeluaran dalam kurun waktu tertentu. Analisis keuntungan atau laba dinilai penting karena dalam laporan keuangan keuntungan merupakan dasar dalam pengambilan keputusan investasi. Tingginya tingkat keuntungan yang diperoleh dalam suatu perusahaan dapat dijadikan sebagai parameter tingkat efisiensi perusahaan dalam menggunakan sumberdaya yang dimiliki.

Tiap kali produksi kerupuk secara manual oleh mitra menghasillan 16 bungkus (16 kg). Dalam seminggu mitra hanya membuat produk selama 3 hari dan dalam sebulan akan menghasilkan bungkus (192 kg). Asumsi produksinya dilakukan selama 12 bulan, maka kapasitas produksinya setahun sebanyak 2.304 bungkus (kg). Sementara itu bila mitra memproduksi kerupuk dengan mesin adonan, tiap harinya dapat menghasilkan 60 bungkus (kg). Dengan asumsi waktu produksi yang sama dengan produksi yang dilakukan secara manual, maka dalam setahun akan dihasilkan 15.000 bungkus (kg). maka bila harga tiap penjualan perbungkus (500 g) adalah Rp 15.000,- maka rasio peningkatan harga produksi kerupuk ikan yang menggunakan mesin pengaduk adonan adalah sebesar 84,64\%. Artinya bahwa penggunaan mesin pengadon dalam pembuatan kerupuk ikan dapat meningkatkan harga produk hampir $85 \%$.

\section{KESIMPULAN}

Kegiatan pengabdian ini telah menambah pengetahuan dan ketrampilan mitra dalam penggunaan mesin pengadonan, kerupuk ikan mitra memiliki permukaan yang lebih merata, tidak retak-retak, dan lebih mengembang. dan penggunaan mesin pengadonan dapat meningkatkan kapasitas produksi dan menurunkan biaya produksi kerupuk ikan. Saran kegiatan pengabdian selanjutnya kepada mitra sasaran adalah pengembangan teknologi pengemasan dan strategi perluasan pemasaran produk kerupuk ikan ini.

\section{UCAPAN TERIMA KASIH}

Kegiatan ini dapat dilaksanakan melalui pendanaan Direktorat Riset dan Pengabdian Masyarakat, Direktorat Jenderal Penguatan Riset dan Pengembangan, Kementerian Riset, Teknologi, dan Pendidikan Tinggi dengan skema Program Kemitraan Masyarakat (PKM) dengan nomer kontrak 050/SP2H/PPM/DRPM/2019, tanggal 18 Maret 2019.

\section{REFERENSI}

Melly, S., Harni, M. 2016. Analisa Ekonomi Pengoperasian Alat Dan Mesin Pengaduk Adonan Kerupuk Merah. Jurnal Teknologi Pertanian Andalas. 20(2):33-38. https://doi.org/10.25077/jtpa.20.2.33-38.2016

Mokhtar, A., Kresno, M.A. 2010. Penggunaan Mesin Pemotong Kcrupuk Hemat Energi untuk Mcningkatkan Produksi dan Kwalitas Kerupuk Rambak Singkong. Jurnal Dedikasi. 7:110-124. https://doi.org/10.22219/dedikasi.v7i0.488

Neiva, C.R.P., Machado, T.M., Tomita, R.Y., Furlan, E.F., Lemos-Neto, M.J., Bastos, D.H.M. 2011. Fish crackers development from minced fish and starch: an innovative approach to a traditional 
product. Food Science and Technology. 31(4):973$979 . \quad$ https://doi.org/10.1590/S010120612011000400024

Rosiani, N., Basito, B., Widowati, E. 2015. Kajian Karakteristik Sensoris Fisik Dan Kimia Kerupuk Fortifikasi Daging Lidah Buaya (Aloe vera) Dengan Metode Pemanggangan Menggunakan Microwave. Jurnal Teknologi Hasil Pertanian. 8(2):84-98. https://doi.org/10.20961/jthp.v0i0.12896

Subramaniam, S.K., Husin, S.H., Yusop, Y., \& Hamidon, A.H. 2008. Machine efficiency and man power utilization on production lines. In Proceedings of the 8th WSEAS International Conference on Electronics, Hardware, Wireless and Optical Communications. 70-75.

Sluková, M., Levková, J., Michalcova, A., Skřivan, P., Skrivan, P. 2017. Effect of the dough mixing process on the quality of wheat and buckwheat proteins. Czech Journal of Food Sciences. 35(6):522-531. https://doi.org/10.17221/220/2017-CJFS

Taewee, T.K. 2011. MiniReview: Cracker "Keropok": A review on factors influencing expansion. International Food Research Journal. 18(3):855866.

Zulfahmi, A.N., Swastawati, F., Romadhon. 2014. Pemanfaatan Daging Ikan Tenggiri (Scomberomorus commersoni) Dengan Konsentrasi Yang Berbeda Pada Pembuatan Kerupuk Ikan. Jurnal Pengolahan dan Bioteknologi Hasil Perikanan. 3(4):133-139.

Zulistyanto, D., Riyadi, P.H., Amalia, U. 2016. Pengaruh Lama Pengukusan Adonan Terhadap Kualitas Fisik Dan Kimia Kerupuk Ikan Lele Dumbo (Clarias gariepinus). Jurnal Pengolahan dan Bioteknologi Hasil Perikanan. 5(4):26-32.

Zzaman, W., Yusoff, M.M., Yang, T.A. 2017. Preparation and properties of fish cracker from different freshwater fish species. International Food Research Journal. 24(5):1858-1862. 